\title{
IDENTIFIKASI KESIAPAN MASYARAKAT DUSUN MULIA MENUJU DESA MANDIRI TAHUN 2019 (STUDI KASUS DUSUN MULIA DESA PERSIAPAN PERMATA JAYA)
}

\author{
Susi Kadarsih ${ }^{1}$, Galuh Bayuardi ${ }^{2}$, Dian Equanti ${ }^{3}$ \\ ${ }^{1,2,3}$ Program Studi Pendidikan Geografi \\ Fakultas Ilmu Pendidikan dan Pengetahuan Sosial IKIP PGRI Pontianak \\ Jalan Ampera Nomor 88 Pontianak - 78116, Telepon (0561) 748219 Fax. (0561) 589855 \\ Alamat e-mail: ${ }^{2}$ zegavon@gmail.com
}

\begin{abstract}
Abstrak
Kabupaten Kubu Raya merupakan pemekaran Kabupaten Mempawah. Pemekaran daerah administrasi bertujuan memudahkan dan meningkatkan pelayanan terhadap masyarakat, mewujudkan daerah yang mampu berkembang secara mandiri, menjaga keseimbangan perkembangan daerah antara daerah baru dengan daerah induknya, menghindari dampak negatif sosial dan menggunakan pendekatan deskriptif kuantitatif dengan bentuk penelitian survey. Instrumen penelitian mengadopsi instrumen Indeks Desa lingkungan akibat adanya pemekaran daerah, meningkatkan pelayanan prasarana dan sarana yang optimal. Tujuan dari penelitian ini adalah untuk mengidentifikasi kesiapan Dusun Mulia RT 05 RW 04 menuju Desa Mandiri ditinjau dari Indeks Desa Membangun dalam dimensi kesehatan, pendidikan, modal sosial dan permukiman. Lokasi penelitian adalah Dusun Mulia RT 04 RW 05 Parit Bangkalan. Metode penelitian Membangun (IDM). Hasil identifikasi tingkat kesiapan Dusun Mulia RT 05 RW 04 menuju Desa Mandiri IDM menunjukkan indeks per dimensi Dusun Mulia RT 05 RW 04 berturut-turut adalah 0,8 untuk dimensi kesehatan; 0,14 untuk dimensi Pendidikan; 0,28 modal sosial; dan 0,8 untuk dimensi permukiman. Rerata keempat indeks ini menghasilkan IDM 0,43. IDM ini termasuk dalam klasifikasi Desa Sangat Tertinggal, artinya Dusun Mulia RT 05 RW 04 tidak siap menuju Desa Mandiri.
\end{abstract}

Kata Kunci: Desa Mandiri; modal sosial; Indeks Desa Membangun;

\begin{abstract}
Kubu Raya Regency is a division of Mempawah Regency. Expansion of the administrative area aims to facilitate and improve services to the community, create regions that are able to develop independently, maintain a balance of regional development between new regions and their parent regions, avoid negative social and environmental impacts due to regional expansion, improve optimal infrastructure and facilities. The purpose of this study was to identify the readiness of Dusun Mulia RT 05 RW 04 becoming Self-Relient Village in terms of the Village Developing Index in the dimensions of health, education, social capital and settlements. The research location is Dusun Mulia RT 04 RW 05 Parit Bangkalan. The research method uses a quantitative descriptive approach in form of survey research. The research instrument adopted the Developing Village Index (Indeks Desa Membangun / IDM) instrument. The identification of the readiness level of Dusun Mulia RT 05 RW 04 becoming Self-Relient Village indicates by IDM results the index of Dusun Mulia RT $05 R W 04$ was 0.8 for the health dimension; 0.14 for the Education dimension; 0.28 social capital; and 0.8 for residential dimensions. The average of these four indices resulted IDM 0.43. This IDM is classified as Very Disadvantaged Villages, means that Dusun Mulia RT 05 RW 04 is not ready toward Self-Relient Village.
\end{abstract}

Keywords: self-relient village; social capital; Developing Village Index;

\section{PENDAHULUAN}


Provinsi Kalimantan Barat terletak di bagian barat Pulau Kalimantan atau di antara garis $2^{0} 08^{\prime} \mathrm{LU}$ serta $3^{0} 02^{\prime} \mathrm{LS}$ serta di antara $108^{0} 30^{\prime} \mathrm{BT}$ dan $114^{\circ} 10^{\prime} \mathrm{BT}$ pada peta bumi. Berdasarkan letak geografis yang spesifik ini maka, daerah Kalimantan Barat tepat dilalui oleh garis Khatulistiwa (garis lintang $0^{0}$ ) tepatnya di atas Kota Pontianak. Dipengaruhi letaknya, maka Kalimantan Barat beriklim tropis dengan temperatur udara cukup tinggi serta diiringi kelembaban yang tinggi. Ciri spesifik Provinsi Kalimantan Barat adalah wilayahnya berbatasan langsung dengan negara asing, yaitu dengan Negara Bagian Sarawak, Malaysia Timur. Dengan posisi ini, maka Kalimantan Barat kini merupakan satu-satunya provinsi di Indonesia yang secara resmi telah mempunyai akses jalan darat untuk masuk dan keluar dari negara asing. Antara Kalimantan Barat dan Sarawak telah terbuka jalan darat antar negara dari Pontianak - Entikong - Kuching (Sarawak, Malaysia) sepanjang sekitar $400 \mathrm{~km}$ dan dapat ditempuh sekitar enam sampai delapan jam perjalanan. Batas-batas wilayah selengkapnya bagi daerah Provinsi Kalimantan Barat adalah Utara: Sarawak (Malaysia), Selatan: Laut Jawa dan Kalimantan Tengah, Timur: Kalimantan Timur, Barat: Laut Natuna dan Selat Karimata menurut BPS Provinsi Kalimatan Barat (2017 8-9).

Pemekaran wilayah atau pembentukan daerah otonomi berdasarkan peraturan Menteri Dalam Negeri Nomor 56 Tahun 2015. Terbentuk daerah otonomi baru yang terdiri dari 34 provinsi, dengan 416 kabupaten dan 98 kota pada tahun 2016. Provinsi Kalimantan Barat hasil pemekaran terdiri dari 12 kabupaten, yaitu Kabupaten Sambas, Kabupaten Bengkayang, kabupaten Landak, Kabupaten Pontianak, Kabupaten Sanggau, Kabupaten Ketapang, Kabupaten Sintang, Kabupaten Kapuas Hulu, Kabupaten Sekadau, kabupaten Melawi, Kabupaten Kayong Utara, Kabupaten Kubu Raya menurut BPS Provinsi Kalimantan Barat (2017: 17). Kabupaten Kubu Raya yang menjadi lokasi penelitian, memiliki ibu kota Kota Kubu. Kabupaten ini merupakan pemekaran dari Kabupaten Mempawah.

Kabupaten Kubu Raya terletak antara $60^{\circ} 08^{\prime}$ Lintang Utara dan antara $94^{\circ}$ $45^{\prime}-141^{0} 05^{\prime}$ Bujur Timur dan dilalui oleh garis Khatulistiwa yang terletak pada garis Lintang $0^{0}$. Kabupaten Kubu Raya merupakan daratan rendah dengan ketinggian rata-rata \pm 84 meter di atas permukaan laut, terletak pada posisi 
0 ${ }^{0} 13$ '40'83" sampai dengan $1^{0} 00$ '53,09" Lintang Selatan serta 109 58 '32,16" Bujur Timur. Luas wilyah Kabupaten Kubu Raya adalah berupa daratan seluas $6.985,24 \mathrm{~km}^{2}$.

Kabupaten Kubu Raya terdiri atas 9 kecamatan yaitu Kecamatan Batu Ampar, Kecamatan Terentang, Kecamatan Kubu, Kecamatan Teluk Pakedai, Kecamatan Sungai Kakap, Kecamatan Rasau Jaya, Kecamatan Sungai Raya, Kecamatan Sungai Ambawang, Kecamatan Kuala Mandor-B, namun lokasi yang diteliti adalah Kecamatan Sungai Raya (BPS Provinsi Kalimantan Barat, 2017 : 12). Kecamatan Sungai Raya memiliki 21 desa. Kecamatan ini langsung berbatasan dengan Kota Pontianak dan memiliki Bandar Udara Internasional Supadio. Desa Persiapan Permata Jaya memiliki lima dusun yaitu: Dusun Mulia, Dusun Suka Maju, Dusun Suka Damai, Dusun Suka Setiya, Dusun Suka Makmur. Dusun Mulia memiliki 13 RT dan dua RW (BPS Provinsi Kalimantan Barat, 2017: 4).

Tujuan pemekaran provinsi di Indonesia adalah untuk memudahkan dan meningkatkan pelayanan terhadap masyarakat, mewujudkan daerah yang mampu berkembang secara mandiri, menjaga keseimbangan perkembangan daerah antara daerah baru dengan daerah induknya, menghindari dampak negatif sosial dan lingkungan akibat adanya pemekaran daerah, meningkatkan pelayanan prasarana dan sarana yang optimal.

Kesiapan adalah tingkat perkembangan yang menguntungkan untuk mempraktekkan sesuatu. Kesiapan masyarakat untuk menghadapi pemekaran daerah di Dusun Mulia, Desa Persiapan Permata Jaya Kabupaten Kubu Raya Provinsi Kalimantan Barat dimaksudkan untuk melihat kesiapan masyarakat menjadi warga desa mandiri. Desa mandiri dilihat dari indikator kondisi kesehatan, kondisi pendidikan, kondisi modal sosial dan kondisi pemukiman. Klasifikasi keempat indikator tersebut adalah: Sangat Tertinggal (Tidak Siap) dengan nilai $\leq$ 0,491; Tertinggal (Kurang Siap) $>0,491$ dan $\leq 0,599$; Berkembang (Cukup Siap) 0,599 dan $\leq 0,707$; Maju (Sangat Siap) $>0,707$ dan $\leq 0,815$; dan Mandiri $>0,815$ (Anwar Sanusi dan Syaiful Huda, 2015: 7).

Untuk mewujudkan Desa Mandiri harus dibarengi dengan pemberdayaan masyarakat desa sebagai pelaku utama. Pemberdayaan masyarakat melalui strategi 
3 (tiga) daya, yaitu pengembangan lumbung ekonomi rakyat; penguatan jaring komunitas wiradesa dan pengembangan lingkar budaya desa (Anwar Sanusi dan Syaiful Huda, 2015: 3). Indikator pemberdayaan masyarakat desa mandiri sebagai berikut:

1. Jaringan Komunikasi Wiradesa adalah melakukan tindakan yang mampu mendorong ekspansi kapabilitas dengan memperkuat daya pada berbagai aspek kehidupan manusia warga Desa yang menjangkau aspek nilai dan moral, serta pengetahuan lokal Desa.

2. Lumbung Ekonomi Desa. Potensi sumber daya di Desa bisa dikonversi menjadi ekonomi yang di dalamnya melibatkan adanya modal, organisasi ekonomi, ada nilai tambah dan mensejahterakan secara ekonomi. Lumbung Ekonomi Desa bukan hanya soal dan untuk produksi, tapi dikapitasi memiliki nilai tambah melalui pendayagunaan teknologi tepat guna dan ramah lingkungan. Pengembangan Lumbung Ekonomi Desa harus mampu menjawab masalah modal, jaringan dan memiliki informasi yang kuat dan oleh karenanya, organisasi ekonomi yang dikembangkan haruslah kompatibel dengan hal tersebut. Lumbung disni ialah kumpulan hasil pertanian pada umunya itu padi, yang di mana Indonesia dengan sumber daya alam yang memadai dan terkenal dengan tanahnya yang subur hingga mendapatkan hasilkan panen yang baik pula.

3. Lingkar Budaya Desa gerakan pembangunan Desa haruslah dilakukan karena kolektivisme, di dalamnya terdapat kebersamaan, persaudaraan dan kesadaran maumelakukan perubahan secara kolektif. Pembangunan Desa hendaknya melampaui pamggilan pribadi. Dana Desa dalam konteks memperkuat pembangunan dan pemberdayaan Desa, misalnya, harus dikritisi agar tidak menjadi bentuk ketergantungan baru. Tidak ada Dana Desa tidaklah boleh sekali-kali dimaknakan sebagai tidak ada pembangunan. Adanya Dana Desa haruslah menghasilkan kemajuan, bukan kemunduran. Maka, pembangunan Desa dimaknai sebagai kerja budaya dengan norma dan moral sebagai pondasinya, sebagai code of conduct, dan dengan begitu perilaku ekonomi dalam kehidupan Desa akan mampu menegakkan martabat dan mensejahterahkan. 
Menurut JP Chaplin yang diterjemahkan oleh Kartini Kartono (Uttoro, 2008: 8), identifikasi adalah proses pengenalan, menempatkan obyek atau individu dengan karakteristik tertentu. Identifikasi berasal dari kata "identify" yang artinya meneliti, menelaah, identifikasi adalah kegiatan yang mencari, menemukan, mengumpulkan, meneliti, mendaftarkan mencatat dan informasi dari lapangan. Menurut Koenjtaraningrat, identifikasi adalah suatu bentuk pengenalan terhadap suatu ciri-ciri fenomena sosial secara jelas dan terperinci (Koenjtaraningrat, 1987: 17). Mengenal secara keseluruhan gejala yang terjadi di masyarakat dengan melihatnya melalui ukuran-ukuran pada gejala yang sama.

Mary Ann (Edwards et.al, 2000) menyederhanakan kesiapan masyarakat ke dalam tiga tingkatan, yaitu: Belum Siap (tiadanya community awareness sekaligus belum memadainya informasi), Dukungan Kolektif (mulai disadarinya peran kolektivitas, leadership, forum komunitas, serta kearifan lokal, namun channelchannel komunikasi dan network masih belum dioptimalkan untuk mendukung pembangunan), hingga Proaktif (dimana masyarakat bersama pengelola proyek mengevaluasi dan memodifikasi kegiatan pembangunan demi efektivitas program selanjutnya). Setiap tingkatan memiliki strategi/pendekatan penanganan yang berbeda, mulai dari: pendekatan personal yang cukup intensif, memanfaatkan media informasi lokal untuk advokasi sekaligus menyampaikan informasi pembangunan, mengoptimalkan sumber daya lokal (baik dari sisikelembagaan, tokoh, media, dsb) dalam rangka menjembatani pihak pemerintah sebagai owner dan masyarakat sebagai user, dan lain-lain. Kesiapan masyarakat ke dalam lima dimensi kesiapan masyarakat, yaitu: Upaya yang dilakukan masyarakat, Pengetahuan masyarakat tentang isu, Kepemimpinan, dan Keterlibatan masyarakat.

Tahapan kesiapan (Edwards et.al, 2000), meliputi yaitu: Tidak Ada Kesadaran (no awareness). Masyarakat atau pemerintah pada umumnya belum menyadari atau mengetahui isu/masalah yang sedang berkembang; Penyangkalan (denial). Hanya segelintir elemen masyarakat yang mengenali isu/masalah tersebut dan mengakui bahwa isu/masalah tersebut sebagai sesuatu yang perlu diperhatikan; Kesadaran Samar (vague awareness). Kebanyakan masyarakat sadar akan potensi lokal dan khawatir akan isu/masalah yang terjadi, namun masyarakat tidak 
melakukan suatu tindakan terhadap isu/masalah tersebut. Kurangnya peran serta pemerintah untuk mengatasi isu/masalah yang terjadi sehingga menyebabkan masyarakat tidak melakukan apapun terhadap isu/masalah yang sedang terjadi; Perencanaan Awal (preplanning). Masyarakat mulai mengorganisasi diri. Ada pengakuan yang jelas akan perlunya melakukan sesuatu untuk menangani isu/masalah yang terjadi, namun upaya tersebut tidak fokus atau rinci. Ada diskusi yang dilakukan, tetapi tidak ada perencanaan dan tindakan yang nyata untuk mengatasi isu/masalah tersebut. Persiapan (preparation). Pemimpin mulai aktif melakukan perencanaan dengan sungguh-sungguh dengan perencanaan yang terfokus dan rinci. Perencanaan yang dibuat lebih terfokus dan rinci. Pada tahap ini muncul pro dan kontra di antara masyarakat akan kebijakan yang dibuat untuk menangani isu/masalah yang terjadi; Inisiasi (initiation). Informasi yang cukup tersedia untuk membenarkan upaya (kegiatan, tindakan atau kebijakan). Suatu kegiatan atau tindakan yang telah dimulai dan sedang berlangsung, tetapi masih dipandang sebagai upaya baru. Pemerintah mulai melaksanakan pelatihan-pelatihan dengan melibatkan masyarakat, namun memiliki keterbatasan karena kurangnya pengalaman dari pemerintah akan pelatihan tersebut. Pada tahap ini masyarakat terlibat dalam segala kegiatan yang dilakukan.

Masyarakat adalah kesatuan hidup manusia yang berinteraksi menurut suatu sistem adat istiadat tertentu yang bersifat kontinyu, dan yang terikat oleh suatu rasa identitas bersama. Kontinuitas merupakan kesatuan masyarakat yang memiliki keempat ciri yaitu: 1) Interaksi antar warga-warganya, 2). Adat istiadat, 3) Kontinuitas waktu, 4) Rasa identitas kuat yang mengikat semua warga (Koentjaraningrat, 2009:115-118). Semua warga masyarakat merupakan manusia yang hidup bersama, hidup bersama dapat diartikan sama dengan hidup dalam suatu tatanan pergaulan dan keadaan ini akan tercipta apabila manusia melakukan hubungan, Mac lver dan Page (dalam Soerjono Soekanto 2006:22), memaparkan bahwa masyarakat adalah suatu sistem dari kebiasaan, tata cara, 19 dari wewenang dan kelima sama antara berbagai kelompok, penggolongan, dan pengawasan tingkah laku serta kebiasaan-kebiasaan manusia. Masyarakat merupakan suatu bentuk kehidupan bersama untuk jangka waktu yang cukup lama sehingga 
menghasilkan suatu adat istiadat, menurut Ralph Linton (dalam Soerjono Soekanto, 2006:22) masyarakat merupakan setiap kelompok manusia yang telah hidup dan bekerja bersama cukup lama, sehingga mereka dapat mengatur diri mereka dan menganggap diri mereka sebagai suatu kesatuan sosial dengan batas-batas yang dirumuskan dengan jelas sedangkan masyarakat menurut Selo Soemardjan (dalam Soerjono Soekanto, 2006:22) adalah orang-orang yang hidup bersama yang menghasilkan kebudayaan dan mereka mempunyai kesamaan wilayah, identitas, mempunyai kebiasaan, tradisi, sikap, dan perasaan persatuan yang diikat oleh kesamaan.

Berdasarkan latar belakang yang ada maka yang menjadi permasalahan penelitian ini adalah : 1. Bagaimana kondisi kesehatan Dusun Mulia; 2. Bagaimana kondisi pendidikan Dusun Mulia; 3. Bagaimana kondisi modal sosial Dusun Mulia; 4. Bagaimana kondisi pemukiman Dusun Mulia; 5. Bagaimana kondisi dusun mulia dengan indeks sosial. Tujuan dari penelitian ini adalah untuk mengidentifikasi kesiapan Dusun Mulia RT 05 RW 04 menuju Desa Mandiri ditinjau dari Indeks Desa Membangun dalam dimensi kesehatan, pendidikan, modal sosial dan permukiman.

\section{METODE}

Pada penelitian sosial ini digunakan pendekatan kuantitatif mengunakan metode deskriptif dengan bentuk penelitian survey. Survey bersifat menyeluruh yang kemudian akan dilanjutkan secara mengkhusus pada aspek tertentu. Lokasi penelitian ini di Parit Bangkalan di RT 05 RW 04. Penelitian ini menggunakan pendekatan kuantitatif guna mengidentifikasi kesiapan masyarakat Dusun Mulia menuju Desa Mandiri. Desain penelitian ini adalah studi Survey, untuk mendapatkan data tentang kesiapan masyarakat Dusun Mulia menuju Desa Mandiri, menginterpretasi dan membandingkan hasil survei dengan indikator yang sudah ditentukan.

Populasi adalah jumlah keseluruhan dari unit analisa yang ciri-cirinya akan diduga (Zuldafrial 2012: 75) sementara itu menurut (Sugiyono 2015: 117) populasi adalah wilayah generalisasi yang terdiri atas: obyek/subyek yang mempunyai 
kualitas dan karakteristik tertentu yang ditetapkan oleh peneliti untuk dipelajari dan kemudian ditarik kesimpulannya. Populasi dalam penelitian ini seluruh rumah tangga adalah di Dusun Mulia yang berjumlah 490 rumah tangga. Dusun Mulia memiliki tiga belas RT dan dua RW.

Teknik pengambilan sampling yang digunakan dalam penelitian ini adalah Cluster Sampling. Menurut Sugiyono, (2015: 121) Cluster Sampling yaitu teknik sampling daerah yang digunakan untuk menentukan sampel bila obyek yang akan diteliti atau sumber data sangat luas, untuk menentukan penduduk mana yang akan dijadikan sumber data, maka pengambilan sampelnya berdasarkan daerah populasi yang telah ditetapkan. Sampel dalam penelitian ini adalah warga di Dusun Mulia Parit Bangkalan di RT 05 RW 04. Unit analisis dalam penelitian ini adalah rumah tangga artinya data menggambarkan kondisi sekelompok orang yang biasanya tinggal bersama dalam suatu bangunan (rumah) serta pengelolaan makan dari satu dapur. Jumlah rumah tangga di daerah penelitian sebanyak 49 unit.

Hatch dan Farhady, 1981 (dalam Sugiyono, 2015: 60) menyatakan bahwa secara teoretis variabel didefinisikan sebagai atribut dari seseorang atau obyek yang mempunyai variasi antara satu orang dengan yang lain, atau satu obyek dengan obyek yang lain. Variabel yang digunakan dalam penelitian ini sebagai berikut:

1. Variabel kesehatan

Indikator variabel kesehatan dilihat dari pelayanan kesehatan yang mencakup waktu tempuh ke prasarana kesehatan, ketersediaan tenaga kesehatan, bidan, dokter, dan nakes. Selain itu, keberdayaan masyarakat untuk kesehatan yang mencakup akses ke Poskesdes maupun Polindes dan Posyandu, begitu juga tingkat aktivitas Posyandu. Jaminan kesehatan yang mencakup tingkat kepersertaan BPJS.

2. Variabel Pendidikan

Indikator variabel Pendidikan dilihat dari akses pendidikan dasar dan menengah, selain itu, akses pendidikan nonformal yang mencakup kegiatan pemberantasan buta aksara, kegiatan PAUD, kegiatan PKBM/Paket ABC. Akses pengeahuan yang mencakup taman bacaan masyarakat atau perpustakaan desa.

3. Variabel Modal Sosial 
Indikator variabel modal sosial dilihat dari masyarakat yang memiliki rasa solidaritas social, mencakup kebiasaan gotong royong, keberadaan ruang publik terbuka bagi warga yang tidak berbayar, ketersediaan fasilitas lapangan olah raga, dan terdapat kelompok kegiatan olah raga. Selain itu terpelihara toleransi yang terwujud dalam perilaku saling menghormati perbedaan suku, agama dan bahasa. Rasa aman penduduk ditandai dengan memelihara Poskamling lingkungan, partisipasi warga mengadakan Siskamling. Kesejahteraan sosial ditandai dengan akses Sekolah Luar Biasa, tidak terdapat penyandang kesehatan sosial (anak jalanan, pekerjaan seks komersial dan pengemis).

\section{Variabel Pemukiman}

Indikator variabel pemukiman meliputi akses air minum bersih dan air minum layak yang mencakup warga memiliki sumber air minum yang layak; dan warga memiliki air untuk mandi dan mencuci. Akses ke sanitasi yang mencakup mayoritas penduduk memiliki jamban, terdapat tempat pembuangan sampah. Akses listrik yang mencakup jumlah keluarga yang memiliki aliran listrik. Akses informasi dan komunikasi yang mencakup penduduk desa memiliki telepon seluler dan sinyal yang kuat, terdapat siaran televisi lokal, nasional dan asing begitu juga terdapat akses internet.

Instrumen yang digunakan dalam penelitian ini diadopsi dari instrumen IDM (Indeks Desa Membangun). Menurut Anwar Sanusi dan Syaiful (2015:7) memnyatakan bahwa Kementerian Desa, Pembangunan Daerah Tertinggal, dan Transmigrasi melalui Direktorat Jenderal Pembangunan dan Pemberdayaan Masyarakat Desa telah mengembangkan program unggulan berdasar tiga (3) pendekatan yang disebut sebagai pilar Desa Membangun Indonesia, yakni: (i) Jaring Komunitas Wiradesa; (ii) Lumbung Ekonomi Desa; dan (iii) Lingkar Budaya Desa. Melalui tiga (3) pilar tersebut diharapkan arah pengembangan program prioritas untuk menguatkan langkah bagi kemajuan dan kemandirian Desa, yang juga mampu dikembangkan sebagai daya lenting dalam peningkatan kesejahteraan kehidupan Desa. Dengan demikian keabsahan instrumen telah teruji oleh tim penyusun IDM tersebut. 
IDM merupakan indeks komposit yang dibangun dari dimensi sosial, ekonomi dan budaya. Ketiga dimensi terdiri dari variabel, dan setiap variabel diturunkan menjadi indikator operasional. Prosedur untuk menghasilkan Indeks Desa Membangun adalah sebagai berikut:

a. Setiap indikator memiliki skor antara 0 s.d. 5; semakin tinggi skor mencerminkan tingkat keberartian. Misalnya: skor untuk indikator akses terhadap pendidikan sekolah dasar; bila Desa A memiliki akses fisik $<=3 \mathrm{Km}$, maka Desa A memiliki skor 5, dan Desa B memiliki akses fisik > $10 \mathrm{Km}$, maka memiliki skor 1. Ini berarti penduduk Desa A memiliki akses yang lebih baik dibandingkan dengan penduduk Desa B.

b. Setiap skor indikator dikelompokkan ke dalam variabel, sehingga menghasilkan skor variabel. Misalnya variabel kesehatan terdiri dari indikator (1) waktu tempuh ke pelayanan kesehatan < 30 menit, (2) ketersediaan tenaga kesehatan dokter, bidan dan nakes lain, (3) akses ke poskesdes, polindes dan posyandu, (4) tingkat aktifitas posyandu dan (5) kepesertaan Badan Penyelenggaraan Jaminan Sosial (BPJS).

c. Indeks dari setiap variabel menjadi Indeks Komposit yang disebut dengan Indeks Desa Membangun (IDM). Dalam penelitian ini yang menjadi prioritas yang dilihat ialah Indeks Sosial yang dimana dilihat dari kondisi pendidikan, kondisi kesehatan, kondisi modal sosial, kondisi pemukiman.

$$
\text { Indeks Variabel : } \frac{\sum \text { Indikator X }}{\text { Nilai Maksimum }(X)}
$$

d. Untuk menetapkan status setiap Desa dilakukan klasifikasi dengan menghitung range yang diperoleh dari nilai maksimum dan minimum. Rentang Nilai yang diperoleh menjadi pembatas status setiap Desa, sehingga ditetapkan lima klasifikasi status Desa yaitu: 
Tabel 1. Klasifikasi Desa Berdasarkan IDM

\begin{tabular}{|c|c|c|}
\hline No & STATUS DESA & NILAI BATAS \\
\hline 1. & Sangat Tertinggal (Tidak Siap) & $\leq 0,491$ \\
\hline 2. & Tertinggal (Kurang Siap) & $>0,491$ dan $\leq 0,599$ \\
\hline 3. & Berkembang (Cukup Siap) & 0,599 dan $\leq 0,707$ \\
\hline 4. & Maju (Sangat Siap) & $>0,707$ dan $\leq 0,815$ \\
\hline 5. & Mandiri & $>0,815$ \\
\hline
\end{tabular}

Sumber: Anwar Sanusi dan Syaiful Huda (2015).

\section{HASIL DAN PEMBAHASAN}

Dusun Mulia di RT 04 RW 05 dari segi kondisi kesehatan cukup memadai seperti pelayanan kesehatan seperti jaminan kesehatan, namun tenaga kesehatan kurang. Dari kondisi lingkungan permukiman, akses jalan kurang memadai. Fasilitas pendidikan baik itu SD, SMP, SMA yang kurang tersedia ruangan Guru dan perpustakaan yang memadai. Dari kondisi ekonomi, tidak tersedia lembaga koperasi, sedangkan untuk menempuh pusat perdagangan sangat jauh dari desa. Demikian pula Kantor Pos dan jasa logistik di RT 04 RW 05 tersebut jauh. Ditinjau dari indikator kesiapan menuju Desa Mandiri, skor desa tersebut tergolong sangat tertinggal (tidak siap).

Indeks Desa Membangun (IDM) lebih fokus pada upaya penguatan otonomi Desa. Indeks ini mengikuti semangat nasional dalam upaya peningkatan kualitas kehidupan desa seperti yang dinyatakan sangat jelas dalam dokumen perencanaan pembangunan nasional melalui optimalisasi pelaksanaan Undang-undang No. 6 Tahun 2014 Tentang Desa (Undang-undang Desa), serta komitmen politik "membangun Indonesia dari Desa" melalui pembentukan kementerian Desa (Kementerian Desa, Pembangunan Daerah Tertinggal dan Transmigrasi) dalam kepemimpinan pemerintahan Kabinet Kerja Jokowi - Jusuf Kalla (Anwar Sanusi dan Syaiful Huda, 2015: 1).

Dusun Mulia kususnya di RT 04 RW 05 dalam mewujudkan Desa mandiri bukan pekerjaan yang mudah. Bagi pendamping desa bukan tugas sederhana. Namun kearifan dan inovasi Desa Mandiri yang membuat desa memiliki peluang untuk bertahan, sejahtera, dan mandiri. Saat ini masyarakat Dusun Mulia di RT 04 
RW 05 belum dapat memanfaatkan potensi-potensi yang ada seperti kebun karet dan lahan yang kosong, sehingga banyak yang lebih memilih bekerja keluar daerah seperti Pontianak, Kapuas hulu, Sekadau dan lainnya. Menurut mereka, bercocok tanam sendiri belum tentu hasilnya sesuai yang diharapkan. Bisa jadi gagal panen, ditambah lagi harga karet yang saat ini turun sehingga tidak cukup untuk memenuhi kebutuhan sehari-hari.

Kondisi perekonomian warga Dusun Mulia RT 05 RW 04 saat penelitian dilakukan memburuk. Hal ini dipengaruhi oleh turunnya harga karet. Akibatnya sebagian warganya bekerja keluar desa untuk memenuhi kebutuhan hidup seharihari. Sumberdaya alam potensial Dusun Mulia RT 05 RW 04 tidak hanya karet, tanahnya juga cukup subur sehingga dapat dimanfaatkan untuk menanam sayursayuran, jahe, jagung, cabai dan sebagainya. Namun banyak warga tidak bisa memberdayakan potensi-potensi tersebut, beberapa faktor penyebabnya antara lain: kurangnya modal usaha, sebagian warga tidak mengerti cara bercocok tanam yang benar, waktu menunggu hasil panen lama, hasil panen kurang memuaskan. Oleh sebab itu masyarakat memilih bekerja keluar desa menuju Sintang, Ambawang, Kapuas Hulu, Pontianak, Sekadau dan lain-lain.

Tabel 2. Hasil Analisis Data IDM (Indek Desa Membangun)

\begin{tabular}{|c|c|c|c|c|c|}
\hline \multirow[b]{2}{*}{ No } & \multicolumn{5}{|c|}{ Hasil Analisis Data } \\
\hline & & Kesehatan & pendidikan & $\begin{array}{c}\text { Modal } \\
\text { sosial }\end{array}$ & permukiman \\
\hline 1 & Jumlah & 196 & 49 & 343 & 343 \\
\hline 2 & $\begin{array}{c}\text { Nilai } \\
\text { maksimum }\end{array}$ & 245 & 343 & 1225 & 686 \\
\hline 3 & Indeks variabel & 0.8 & 0.14 & 0.28 & 0.5 \\
\hline
\end{tabular}

Sumber: Analisis Survei Data Primer 2019.

Klasifikasi Desa Berdasar IDM menunjukkan, masyarakat Dusun Mulia RT 05 RW 04 berada dalam klasifikasi desa sangat tertinggal (tidak siap). Kondisi masyarakat yang ada di Dusun Mulia di RT 05 RW 04 permasalahan yang ada di lapangan adalah tentang perekonomian yang kurang memadai semenjak turunnya 
harga karet. Semenjak harga karet turun, sebagian masyarakatnya sudah tidak menoreh lagi. begitu juga masyarakat tersebut sebagaian belum bisa memanfaatkan potensi yang ada seperti lahan kosong yang terbengkalai di Parit Bangkalan. Masyarakat lebih memilih bekerja keluar daerah untuk mencari nafkah dengan tujuan Pontianak, Sanggau, Kapuas Hulu, Sekadau, Ambawang dan ada juga yang menjadi TKI ke luar negeri. Mereka yang bekerja di Pontianak, biasanya berprofesi sebagai buruh bangunan, sedangkan yang bekerja di daerah hulu (kabupaten pedalaman) bekerja sebagai buruh penggarap perkebunan kelapa sawit.

Kondisi kesehatan yang ada di Dusun Mulia RT 05 RW 04 Desa termasuk kategori mandiri, dengan adanya pelayanan kesehatan begitu juga tersedianya tenaga kesehatan, bidan, dokter, tenaga kesehatan dan ada keberdayaan masyarakat untuk kesehatan yang berupa akses ke Poskesdes, Polindes dan Posyandu serta ada kepesertaan masyarakat pada jaminan kesehatan berupa BPJS.

Kondisi pendidikan yang ada di Dusun Mulia khusus di RT 05 RW 04 sarana prasarana yang ada di daerah tersebut kurang memadai karena akses pendidikan menengah jangkauannya cukup jauh kecuali untuk tingkatan dasar yang masing mudah untuk di jangkau, begitu juga untuk akses kependidikan nonformal yang ada daerah tersebut sperti kegiatan pemberantasan buta aksara tidak ada dan juga kegiatan PAUD tidak ada apalagi untuk kegiatan PKBM/paket ABC tidak ada serta untuk taman baca juga tidak ada. Begitulah kondisi pendidikan yang ada di Parit Bangkalan RT 05 RW 04 sangat kurang memadai banyak fasilitas-fasilitas yang kurang.

Kondisi modal sosial yang ada di Dusun Mulia RT 05 RW 04 dari hasil penelitian ini sangat kurang. Solidaritas sosial seperti kebiasaan bergotong-royong masih ada. Namun keberadaan ruang publik terbuka bagi warga yang tidak berbayar tidak ada. Fasilitas lapangan olah raga hanya tersedia lapangan sepak bola, dan kelompok kegiatan olah raga hanya ada sepak bola. Dilihat dari rasa toleransi, warga desa terdiri dari satu suku yaitu suku Madura warga tersebut berkomunikasi sehari-hari menggunakan bahasa Madura dan menganut agama Islam. Akses penduduk ke pusat perdagangan yang ada di Parit Bangkalan ini hanya ada pertokoan seperti warung yang biasanya terdapat di daerah-daerah terpencil, bukan 
supermarket seperti di kota pada umumnya. Di Dusun Mulia RT 05 RW 04 tidak ada terdapat lembaga perbankan, dan tidak ada lembaga ekonomi rakyat (koperasi). Juga tidak ada usaha kedai makanan, restoran apalagi penginapan.

Dilihat dari kondisi pemukiman, Dusun Mulia RT 05 RW 04 memiliki sarana prasarana yang cukup baik. Mayoritas penduduk memiliki sumber air minum layak dan sumber air untuk mandi dan mencuci. Penduduk juga memiliki akses aliran listrik, serta sebagian sudah menggunakan telepon seluler dengan sinyal cukup baik. Provider telekomunikasi yang banyak digunakan adalah Telkomsel dan Indosat. Di Parit Bangkalan ini tidak ada pencemaran air yang berasal dari limbah serta aman dari bencana longsor.

\section{SIMPULAN}

Hasil identifikasi tingkat kesiapan Dusun Mulia RT 05 RW 04 menuju Desa Mandiri menurut Indeks Desa Membangun (IDM) menunjukkan indeks per dimensi Dusun Mulia RT 05 RW 04 berturut-turut adalah 0,8 untuk dimensi kesehatan; 0,14 untuk dimensi Pendidikan; 0,28 modal sosial; dan 0,8 untuk dimensi permukiman. Rerata keempat indeks ini menghasilkan IDM 0,43. IDM ini termasuk dalam klasifikasi Desa Sangat Tertinggal, artinya Dusun Mulia RT 05 RW 04 tidak siap menuju Desa Mandiri.

\section{DAFTAR PUSTAKA}

Anwar Sanusi, dan Syaiful Huda. (2015). Indeks Desa Membangun. Jakarta Selatan: Kementrian Desa, Pembangunan Daerah Tertinggal dan Transmigrasi.

BPS Provinsi Kalimantan Barat. 2017. Provinsi Kalimantan Barat Dalam Angka 2017. Pontianak: BPS Provensi Kalimantan Barat.

BPS Provinsi Kalimantan Barat. 2017. Kabupaten Kubu Raya Dalam Angka 2017. Pontianak: BPS Kabupaten Kubu Raya.

BPS Provinsi Kalimantan Barat. 2017. Kecamatan Sungai Raya Dalam Angka 2017. Pontianak: BPS Kabupaten Kubu Raya.

Koentjaraningrat, 1987. Sejarah Teori Antropologi. Jakarta: UI-Press. 
2017. Pengertian Identifikasi, (https://id.wikipedia.org/wiki/Identifikasi, diakses 06 November 2018, Jam 20:30 WIB).

Mary Ann, 2000. Pengertian Kesiapan, (repository.usu.ac.id/bitstream/ diakses 10 Oktober 2018, Jam 21:03 WIB.

Sugiyono. (2015). Metode penelitian Pendidikan (Pendekatan Kuantitatif Kualitatif, dan $R \& D$. Bandung: Alfabeta.

Zuldafrial. (2009). Pendekatan Penelitian dan Teknik Penulisan Karya Ilmiah. Yogyakarta: Media Perkasa.

Zuldafrial. (2012) Penelitian Kuantitatif. Yogyakarta: Media Perkasa. 